\section{Occupational lung disease \\ S1 EVIDENCE-BASED CASE DEFINITION FOR EAA DUE TO METALWORKING FLUID EXPOSURE}

doi:10.1136/thoraxjnl-2011-201054b.1

${ }^{1} \mathrm{C} M$ Barber, ${ }^{1} \mathrm{C}$ M Burton, ${ }^{2} \mathrm{D}$ J Hendrick, ${ }^{3} \mathrm{C}$ A C Pickering, ${ }^{4} \mathrm{~A} S$ Robertson, ${ }^{5}$ W Robertson, ${ }^{4} \mathrm{P}$ S Burge. ${ }^{1}$ Centre for Workplace Health, Buxton, UK; ${ }^{2}$ University of Newcastle, Newcastle, UK; ${ }^{3}$ Wythenshawe Hospital, Manchester, UK; ${ }^{4}$ Heart of England Hospital, Birmingham, UK; ${ }^{5}$ University of Warwick, Coventry, UK

Introduction and objectives Although a number of case definitions for MWF EAA have been used in previous outbreaks, none has emerged as an evidence-based standard. This study used data from a large UK MWF outbreak investigation, to develop and validate a new case definition for MWF EAA.

Methods Demographic and clinical data from the 37 workers with suspected EAA during a large outbreak were reviewed by an Expert Panel. A new case definition for MWF EAA was developed using significant differences between workers with and without definite clinical EAA. This MWF EAA Score was modelled to match Expert Panel opinion as closely as possible, and used clinical criteria relatively weighted by their positive predictive value for EAA in the outbreak. The performance of the new scoring system was compared with other existing case definitions, and applied to 50 cases of MWF-EAA from nine published US outbreaks.

Results The MWF EAA Score is shown in Abstract S1 table 1, where the highest score is applied in each section. A score of $>26$ represents definite EAA, 19-26 possible EAA, and $<19$ not a case of EAA. When applied to the 37 workers, the MWF EAA Score showed good correlation (coefficient $=0.85$ ) with the Expert Panel Score (per cent likelihood of EAA), and agreed with the Expert Panel opinion in 81\% of cases. The MWF EAA Score appeared to perform well when compared with other established case definitions, and when applied to 50 US cases of MWF EAA.

Abstract S1 Table 1 MWF EAA Score for workers with suspected EAA during MWF outbreaks

\begin{tabular}{lc}
\hline Respiratory symptoms & +4 \\
Work-related cough/wheeze/sob/chest tightness & +6 \\
Stopping for breath when walking at own pace on level ground & +7 \\
Previous time off work with any chest illness & \\
Constitutional symptoms & +5 \\
Recurrent flu-like symptoms worse at the end of the working week & +7 \\
Unexplained weight loss & +3 \\
Physiology & +5 \\
FVC $<80 \%$ predicted & +10 \\
FVC $<70 \%$ predicted or Tlco $<80 \%$ predicted & \\
Tlco $<60 \%$ predicted & +6 \\
Radiology/clinical examination & +7 \\
Abnormal CXR (diffuse ground glass or nodularity) & +7 \\
Abnormal HRCT (ground glass, nodularity, mosaic, or UIP fibrosis) & \\
Fine end-inspiratory crepitations on auscultation & +5 \\
Evidence of inflammation & +8 \\
Neutrophilia $>7$ or CRP $\geq 10$ & +10 \\
BAL lymphocytosis $\geq 20 \%$ & $/ 41$ \\
Lung biopsy typical of EAA (sub-acute EAA or UIP) & \\
Total (max 41 ) & +7 \\
\hline
\end{tabular}

Conclusions Although difficult to truly validate, the MWF EAA Score offers a weighted and evidence-based case definition for workers suspected of suffering from EAA in MWF outbreaks. If adopted as a standard, the MWF EAA score will facilitate comparison of the findings from future outbreaks, in terms of risk factors and causation of this interesting disease.
OCCUPATIONAL EXPOSURE, BREATHLESSNESS AND COPD IN A GENERAL POPULATION OF OLDER UK MEN

doi:10.1136/thoraxjnl-2011-201054b.2

${ }^{1}$ E Pickles, ${ }^{2} \mathrm{~J}$ Szram, ${ }^{1} \mathrm{~S}$ J Schofield, ${ }^{1} \mathrm{~A}$ P M Woods, ${ }^{1} \mathrm{P}$ Cullinan. ${ }^{1}$ Imperial College, London, UK; ${ }^{2}$ Royal Brompton and Harefield NHS Foundation Trust, London, UK

Most COPD is attributable to smoking, however evidence from workforce and general population studies suggest that occupational exposure is also associated with the disease. This study examines the relationship between respiratory symptoms, doctor-diagnosed COPD and occupational exposure in a general UK population Lifetime occupational and smoking history, doctor-diagnosed disease and current respiratory symptoms were collected by postal questionnaire in a cohort of subjects aged $51-60$, recruited from 33 general practices in Kent; here we present the results in men $(n=3011)$. Occupations were defined a priori as being associated with an increased risk of COPD using 13 job categories as defined for the European Community Respiratory Health Survey ${ }^{1}$; all other occupations were designated low risk (referent). Logistic regression in men with complete data and no history of asthma $(n=2452)$ demonstrated a statistically significant increase in both the odds of breathlessness (modified MRC score 1 or greater, Abstract S2 table 1) and breathlessness reported along with symptoms of chronic bronchitis (data not shown) in subjects who had a history of ever having been employed in a risky job, compared to other referent (mainly white collar) workers. This association, between work in

Abstract S2 Table 1 Logistic regression: relationship between breathlessness in men and ever working in an occupational group with an a priori risk of COPD (as defined for the ECRHS) compared to referent occupations

\begin{tabular}{|c|c|c|c|c|c|}
\hline $\begin{array}{l}\text { ECRHS } \\
\text { occupational } \\
\text { groups at } \\
\text { risk of COPD }\end{array}$ & Total (n) & $\begin{array}{l}\text { Subjects } \\
\text { reporting } \\
\text { breathlessness } \\
(\mathrm{n}, \%)\end{array}$ & $\begin{array}{l}\text { Crude OR } \\
(95 \% \mathrm{CI})\end{array}$ & $\begin{array}{l}\text { Adjusted* } \\
\text { OR (95\%CI) }\end{array}$ & $\mathbf{p}$ \\
\hline $\begin{array}{l}\text { Referent } \\
\text { occupations }\end{array}$ & 654 & $84(12.8)$ & 1.0 & 1.0 & na \\
\hline $\begin{array}{l}\text { Ever working } \\
\text { in an at } \\
\text { risk job }\end{array}$ & 1798 & $379(21.1)$ & $\begin{array}{l}1.81 \\
(1.40 \text { to } 2.34)\end{array}$ & $\begin{array}{l}1.57 \\
\text { (1.21 to } 2.04)\end{array}$ & 0.001 \\
\hline Cleaning & 120 & $38(31.7)$ & $\begin{array}{l}3.14 \\
(2.00 \text { to } 4.92)\end{array}$ & $\begin{array}{l}2.62 \\
(1.64 \text { to } 4.17)\end{array}$ & $<0.001$ \\
\hline Painting & 88 & $26(29.6)$ & $\begin{array}{l}2.85 \\
(1.70 \text { to } 4.75)\end{array}$ & $\begin{array}{l}2.22 \\
(1.30 \text { to } 3.80)\end{array}$ & 0.003 \\
\hline Agriculture & 190 & $53(27.9)$ & $\begin{array}{l}2.63 \\
\text { (1.78 to } 3.88)\end{array}$ & $\begin{array}{l}2.31 \\
(1.54 \text { to } 3.45)\end{array}$ & $<0.001$ \\
\hline Transport & 566 & $151(26.7)$ & $\begin{array}{l}2.47 \\
\text { (1.84 to } 3.32 \text { ) }\end{array}$ & $\begin{array}{l}2.07 \\
(1.52 \text { to } 2.81)\end{array}$ & $<0.001$ \\
\hline Food & 128 & $34(26.6)$ & $\begin{array}{l}2.45 \\
(1.56 \text { to } 3.87)\end{array}$ & $\begin{array}{l}1.96 \\
(1.20 \text { to } 3.2)\end{array}$ & 0.007 \\
\hline Healthcare & 126 & $30(23.8)$ & $\begin{array}{l}2.12 \\
\text { (1.33 to } 3.39)\end{array}$ & $\begin{array}{l}1.96 \\
(1.21 \text { to } 3.16)\end{array}$ & 0.006 \\
\hline $\begin{array}{l}\text { Other } \\
\text { manual } \\
\text { work }\end{array}$ & 307 & $76(24.8)$ & $\begin{array}{l}2.23 \\
(1.58 \text { to } 3.12)\end{array}$ & $\begin{array}{l}1.81 \\
(1.26 \text { to } 2.60)\end{array}$ & 0.001 \\
\hline Wood & 234 & $54(23.1)$ & $\begin{array}{l}2.04 \\
(1.39 \text { to } 2.98)\end{array}$ & $\begin{array}{l}1.81 \\
\text { (1.23 to } 2.68)\end{array}$ & 0.003 \\
\hline Construction & 389 & $92(23.7)$ & $\begin{array}{l}2.10 \\
\text { (1.52 to } 2.92)\end{array}$ & $\begin{array}{l}1.73 \\
\text { (1.23 to } 2.43)\end{array}$ & 0.002 \\
\hline Mining & 378 & $81(21.4)$ & $\begin{array}{l}1.85 \\
\text { (1.32 to } 2.59 \text { ) }\end{array}$ & $\begin{array}{l}1.44 \\
(1.01 \text { to } 2.04)\end{array}$ & 0.045 \\
\hline $\begin{array}{l}\text { Metal } \\
\text { industries }\end{array}$ & 586 & $113(19.3)$ & $\begin{array}{l}1.62 \\
(1.19 \text { to } 2.20)\end{array}$ & $\begin{array}{l}1.38 \\
(1.00 \text { to } 1.89)\end{array}$ & 0.048 \\
\hline Electrical & 293 & $51(17.4)$ & $\begin{array}{l}1.43 \\
\text { (0.98 to } 2.09 \text { ) }\end{array}$ & $\begin{array}{l}1.32 \\
(0.90 \text { to } 1.94)\end{array}$ & 0.159 \\
\hline Chemical & 110 & $15(13.6)$ & $\begin{array}{l}1.07 \\
(0.59 \text { to } 1.93)\end{array}$ & $\begin{array}{l}0.82 \\
(0.51 \text { to } 1.71)\end{array}$ & 0.822 \\
\hline
\end{tabular}

Crude ORs and *adjusted for age and smoking (by pack year history) are shown. 
occupations with an a priori risk of COPD and chronic respiratory symptoms, remained after adjustment for age and smoking status, using pack year history. The strength of the relationship between symptoms and work varied by occupational type; cleaners, painters and agricultural workers had the highest risk of breathlessness when compared to the referent population (Abstract S2 table 1). An increased risk of doctor-diagnosed COPD (COPD, chronic bronchitis or emphysema) was also found in cleaners, transport workers, wood and construction workers (data not shown); in comparison with the prevalence of respiratory symptoms, the number of men declaring doctor-diagnosed disease was small (21\% vs $5 \%)$. This study demonstrates an association between occupational exposure, chronic respiratory symptoms and doctordiagnosed COPD within a general population of older males in the UK independent of smoking history. Further characterisation of the cohort, using the results of spirometry, will allow the relationship between risky job exposure and disease to be examined in more detail.

\section{REFERENCE}

1. European Community Respiratory Health Survey.

\section{S3 WORK PERFORMANCE AND AIRFLOW OBSTRUCTION IN A GENERAL UK POPULATION OF OLDER WORKERS}

doi:10.1136/thoraxjnl-2011-201054b.3

${ }^{1} \mathrm{~J}$ Szram, ${ }^{2} \mathrm{~S}$ J Schofield, ${ }^{2}$ A P M Woods, ${ }^{2} \mathrm{~N}$ Crisp, ${ }^{2} \mathrm{D}$ Harris, ${ }^{2} \mathrm{P}$ Cullinan. ${ }^{1}$ Royal Brompton and Harefield NHS Foundation Trust, London, UK; ${ }^{2}$ Imperial College, London, UK

Work disability as a consequence of COPD has been found in a number of patient cohorts and respiratory symptoms were shown to be significantly associated with work limitation in the Lungs at Work study. ${ }^{1}$ The impact of airflow obstruction on impaired work performance in the general population is unknown. The clinical assessment was designed to examine the relationship between respiratory symptoms and work performance in a general population of older workers in more detail. Volunteers in full time employment at the time of the initial postal questionnaire study (of 51 to 60-year olds through general practice) underwent clinical assessment, including spirometry $(n=1773)$. Results are shown in Abstract S3 table 1. Prevalence of declared doctor-diagnosed COPD was low $(1.9 \%$ of men and $0.6 \%$ of women) compared to that of airflow obstruction on spirometry (post-bronchodilator $\mathrm{FEV}_{1}<80 \%$ predicted and $\mathrm{FEV}_{1} / \mathrm{FVC}$ ratio $<0.7$ ) was higher, similar to previous published estimates. Men and women with airflow obstruction had a significantly higher prevalence of poor self-reported performance at work than individuals with normal spirometry. Subjects of both sexes with abnormal spirometry who also reported high levels of physical activity in their current job were significantly more likely to report poor work performance than individuals without airflow obstruction with similarly high activity levels; this difference was not seen in low activity work (data not shown). Men were significantly more likely than women to predict that they would stop work due to ill-health. In both sexes, participants with abnormal spirometry were significantly more likely to predict ill-health retirement than individuals with normal lung function. This study has demonstrated an association between airflow obstruction and both work performance within a general population of older workers; the level of physical activity required at work had an important effect on this relationship. Future loss from the workforce due to ill-health was also related to lung function. Detection of airflow obstruction could aid retention in employment, provided that suitable interventional strategies are in place to support older workers.
Abstract S3 Table 1 Self-reported work performance, physical activity and current work exposures in a general population of adults aged 51-60 in full time employment $(n=1773)$, stratified by sex and airflow obstruction

\begin{tabular}{lccr}
\hline & Men (n=1101) & Women (n=672) & \\
& $\mathbf{n}, \%$ & n $\%$ & p Value \\
\hline Poor work performance & $112(10.4)$ & $54(8.2)$ & 0.128 \\
High level of physical activity at work & $496(46.1)$ & $227(34.6)$ & $<0.001$ \\
Airflow obstruction* $^{*}$ & $77(7.3)$ & $25(3.9)$ & 0.004 \\
Health will limit ability to work & $568(52.1)$ & $271(40.7)$ & $<0.001$
\end{tabular}

\begin{tabular}{|c|c|c|c|c|c|c|}
\hline \multirow[b]{3}{*}{$\begin{array}{l}\text { Poor work } \\
\text { performance }\end{array}$} & \multicolumn{2}{|c|}{ Airflow obstruction* $n, \%$} & \multirow{2}{*}{\multicolumn{2}{|c|}{$\begin{array}{c}\text { Yes } \\
\text { p Value }(n=25)\end{array}$}} & \multirow{3}{*}{$\begin{array}{l}\begin{array}{l}\text { No } \\
(n=617)\end{array} \\
48(7.9)\end{array}$} & \multirow{3}{*}{$\frac{\text { p Value }}{0.032}$} \\
\hline & \multirow{2}{*}{$\begin{array}{l}\begin{array}{l}\text { Yes } \\
(\mathbf{n}=77)\end{array} \\
13(16.9)\end{array}$} & \multirow{2}{*}{$\begin{array}{l}\begin{array}{l}\text { No } \\
(\mathbf{n}=977)\end{array} \\
90(9.4)\end{array}$} & & & & \\
\hline & & & 0.035 & $5(20.0)$ & & \\
\hline $\begin{array}{l}\text { Poor work } \\
\text { performance } \\
\text { and high level of } \\
\text { physical activity } \\
\text { at work }\end{array}$ & 11(30.6) & $58(13.4)$ & 0.005 & $3(23.1)$ & $15(7.5)$ & 0.084 \\
\hline $\begin{array}{l}\text { Health will limit } \\
\text { ability to work }\end{array}$ & $50(64.9)$ & $495(51.2)$ & 0.020 & $16(64.0)$ & $9(36.0)$ & 0.016 \\
\hline
\end{tabular}

${ }^{*}$ Post-bronchodilator $\mathrm{FEV}_{1}<80 \%$ predicted and $\mathrm{FEV}_{1} / \mathrm{FVC}$ ratio $<0.7$

\section{REFERENCE}

1. Szram J, Schofield SJ, Woods APM, et al. Breathlessness, respiratory disease and work performance in older adults. British Thoracic Society Conference 2010. Poster: P4.

\section{S4 OCCUPATIONAL ASTHMA; IS THIS THE CAUSE OF EXCESS RESPIRATORY SYMPTOMS AND COPD DESCRIBED IN BITUMEN EXPOSED WORKERS?}

doi:10.1136/thoraxjnl-2011-201054b.4

N Surange, J Hoyle. North Manchester General Hospital, Penine Acute NHS Trust, Manchester, UK

Introduction Epidemiological studies suggest increased risk of asthma and COPD in asphalt exposed workers. ${ }^{1}$ Bitumen is used in this industry. In this case we describe occupational asthma caused by bitumen exposure in a lab environment. This is the first such report to our knowledge.

Case History A 49-year old male with no history of asthma or atopy and $<5$ pack years smoking history presented with airflow obstruction on surveillance spirometry, cough and wheeze. He analysed hot bitumen samples (1900 C) in a lab environment without using respiratory protective equipment. Spirometry FEV 1 57\%, FVC 85\% ratio $55 \%$. Respiratory symptoms improved after 3 weeks off work, returning soon after he rejoined the lab. Peak flow rates were variable and lower at work. Analysis with OASYS scored 3.08 (Abstract S4 figure 1). Histamine challenge test was positive $\left(\mathrm{PC}_{20} 2.216 \mathrm{mg} / \mathrm{ml}\right)$. Skin prick test to paraldehyde was positive. After 8 weeks away from the exposed environment the subject was asymptomatic, continued to have obstructive spirometry but improved bronchial reactivity $\left(\mathrm{PC}_{20} 7.489 \mathrm{mg} / \mathrm{ml}\right.$ ) without medication and improved peak flows with little diurnal variation. One week after restarting work the respiratory symptoms returned. Repeat OASYS charts scored 3.14 with histamine reactivity similar to baseline $\left(\mathrm{PC}_{20} 2.81 \mathrm{mg} / \mathrm{ml}\right)$ after 4 weeks. A specific challenge test was not possible due to the problems with heating bitumen to $1900^{\circ} \mathrm{C}$ in the hospital lab.

Conclusion The progression of symptoms and lung function in relation to work history supports the diagnosis of occupational asthma induced by bitumen fume exposure. This has not been reported previously. The possible mechanisms include sensitisation to short chain aldehydes, produced by partial combustion of 